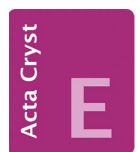

CRYSTALLOGRAPHIC COMMUNICATIONS

ISSN 2056-9890

Received 20 August 2019

Accepted 10 October 2019

Edited by E. V. Boldyreva, Russian Academy of Sciences, Russia

Keywords: crystal structure; cocrystal; Hirshfeld surface; 2-chloro-5-nitrobenzoic acid; nicotinamide.

CCDC reference: 1958621

Supporting information: this article has supporting information at journals.iucr.org/e

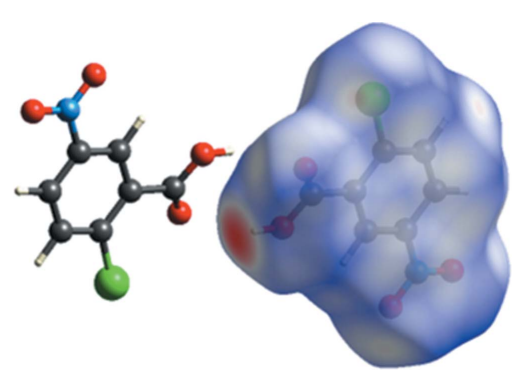

OPEN Ә ACCESS

\section{Crystal structure of a 1:1 cocrystal of nicotinamide with 2-chloro-5-nitrobenzoic acid}

\author{
Keshab M. Bairagi, ${ }^{a}$ Priyanka Pal, ${ }^{a}$ Subhrajyoti Bhandary, ${ }^{b}$ Katharigatta N. \\ Venugopala, ${ }^{c, d *}$ Deepak Chopra ${ }^{b}$ and Susanta K. Nayak ${ }^{a *}$
}

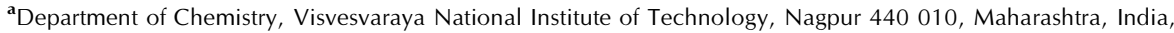
bepartment of Chemistry, Indian Institute of Science Education and Research Bhopal, Bhauri, Bhopal 462 066, Madhya Pradesh, India, ' Department of Pharmaceutical Sciences, College of Clinical Pharmacy, King Faisal University, Al-Ahsa 31982, Kingdom of Saudi Arabia, and ${ }^{\mathbf{d}}$ Department of Biotechnology and Food Technology, Durban University of Technology, Durban 4001, South Africa. *Correspondence e-mail: kvenugopala@kfu.edu.sa, sknayak@chm.vnit.ac.in

In the title 1:1 cocrystal, $\mathrm{C}_{7} \mathrm{H}_{4} \mathrm{ClNO}_{4} \cdot \mathrm{C}_{6} \mathrm{H}_{6} \mathrm{~N}_{2} \mathrm{O}$, nicotinamide (NIC) and 2-chloro-5-nitrobenzoic acid (CNBA) cocrystallize with one molecule each of NIC and CNBA in the asymmetric unit. In this structure, CNBA and NIC form hydrogen bonds through $\mathrm{O}-\mathrm{H} \cdots \mathrm{N}, \mathrm{N}-\mathrm{H} \cdots \mathrm{O}$ and $\mathrm{C}-\mathrm{H} \cdots \mathrm{O}$ interactions along with $\mathrm{N}-\mathrm{H} \cdots \mathrm{O}$ dimer hydrogen bonds of NIC. Further additional weak $\pi-\pi$ interactions stabilize the molecular assembly of this cocrystal.

\section{Chemical context}

Nicotinamide (NIC) derivatives are used in various applications, for example, in the prevention of type 1 diabetes (Elliott et al., 1993) and nicotinamide cofactors are also used in preparative enzymatic synthesis (Chenault \& Whitesides, 1987). The nicotinamide formulation has also been used for treatment in palliative radiotherapy (Horsman et al., 1993). The pharmacological result for the active pharmaceutical ingredient (API) will increase if it becomes cocrystallized with a coformer or other active component (Schultheiss \& Newman, 2009; Lemmerer et al., 2010). Chlorobenzoic acid derivatives are widely used in the pharmaceutical industry. 2Chloro-4-nitrobenzoic acid is used for immunodeficiency diseases as an antiviral and anticancer agent (Lemmerer et al., 2010). In the title compound, NIC is cocrystallized with the CNBA coformer as it acts as an excellent candidate for cocrystallization because of the hydrogen-bond acceptor and donor parts (Dragovic et al., 1995).

\section{Structural commentary}

The title compound CNBA-NIC (1:1) crystallizes in the monoclinic space group $P 2_{1} / c$ with four molecules of NIC and

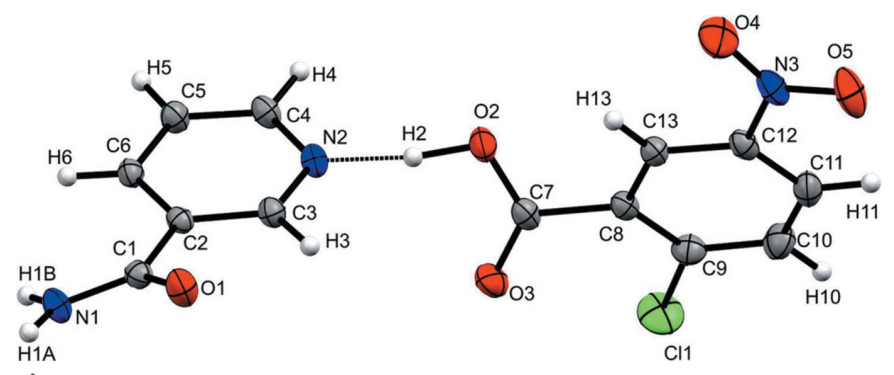

Figure 1

The asymmetric unit of the title compound, showing $50 \%$ probability ellipsoids, the atom labelling and hydrogen bonding with dotted lines. 


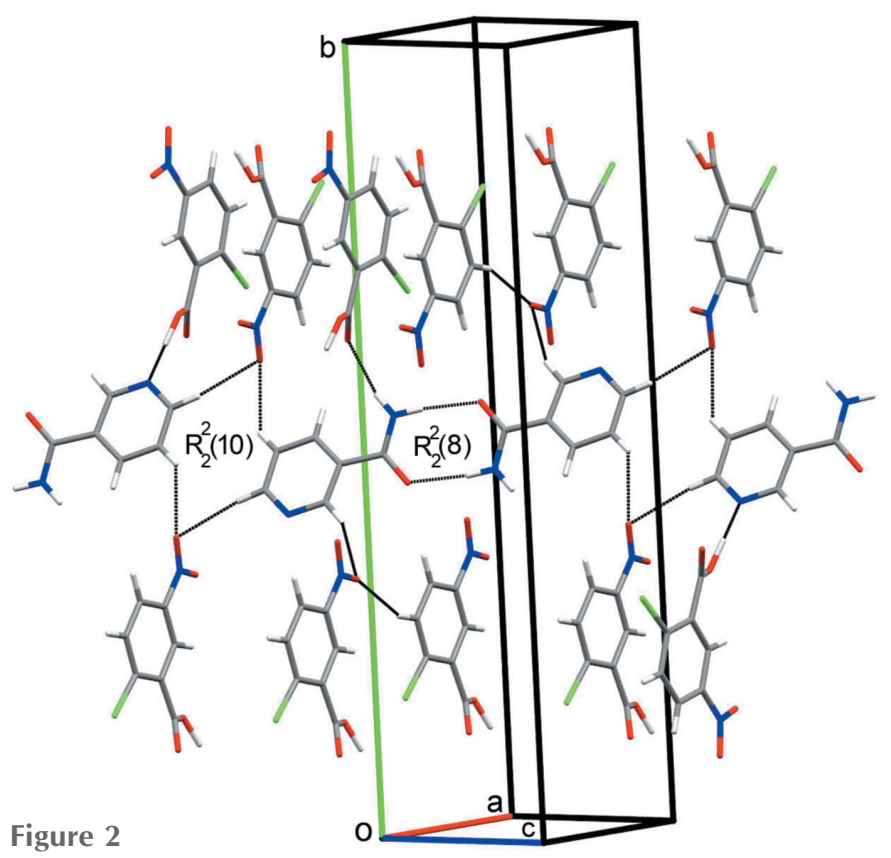

Hydrogen bonds in the title compound showing the dimer formation through $\mathrm{N}-\mathrm{H} \cdots \mathrm{O}$ interactions and tetramer formation through $\mathrm{C}-$ $\mathrm{H} \cdots \mathrm{O}$ interactions.

CNBA in the unit cell. The dihedral angle between the amide plane with the mean plane of the phenyl part in NIC is

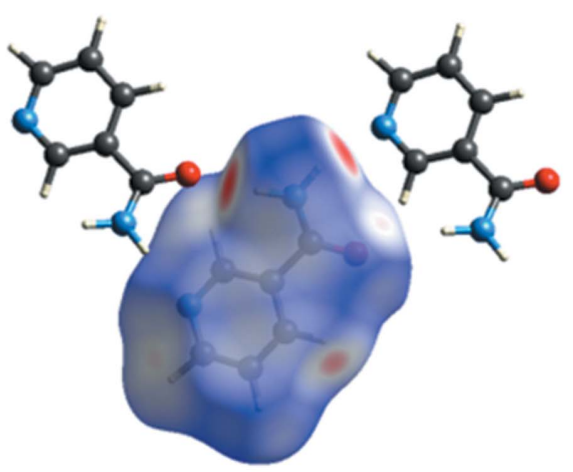

(i) dnorm mapped over pure NIC

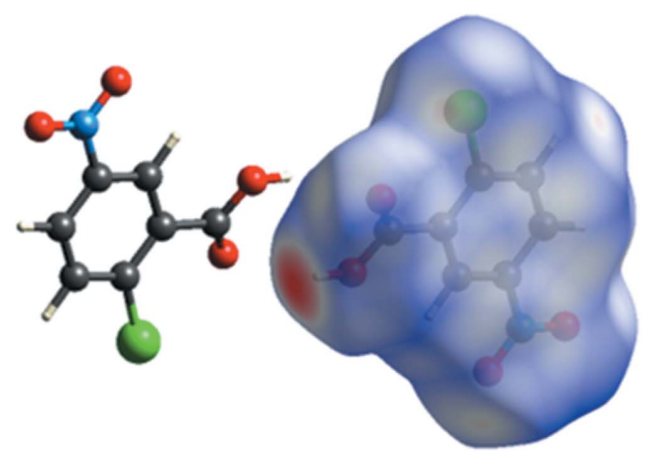

Figure 4

(iii) dnorm mapped over pure CNBA

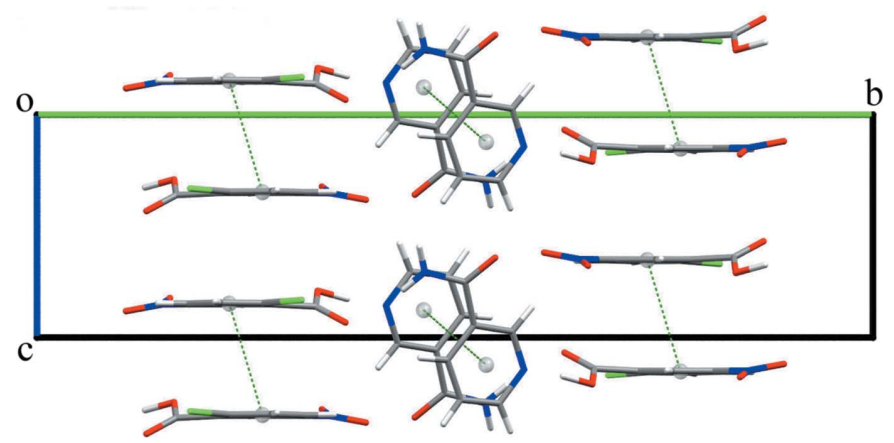

Figure 3

Weak $\pi-\pi$ interactions stabilize the molecular assembly of both molecules in the crystal.

$23.87(1)^{\circ}$, and the dihedral angles of the carboxyl and nitro groups with the chlorophenyl ring in CNBA are 24.92 (1) and $3.56(1)^{\circ}$, respectively. In the asymmetric unit, an (CNBA)O$\mathrm{H} \cdots \mathrm{N}$ interaction plays a prime role in the molecular recognition of this cocrystal (Fig. 1).

\section{Supramolecular features}

In the crystal structure of the title cocrystal, a strong (CNBA)O $-\mathrm{H} \cdots \mathrm{N}(\mathrm{NIC})$ hydrogen bond and additional $(\mathrm{NIC}) \mathrm{N}-\mathrm{H} \cdots \mathrm{O}(\mathrm{CNBA})$ and $(\mathrm{NIC}) \mathrm{C}-\mathrm{H} \cdots \mathrm{O}(\mathrm{CNBA})$

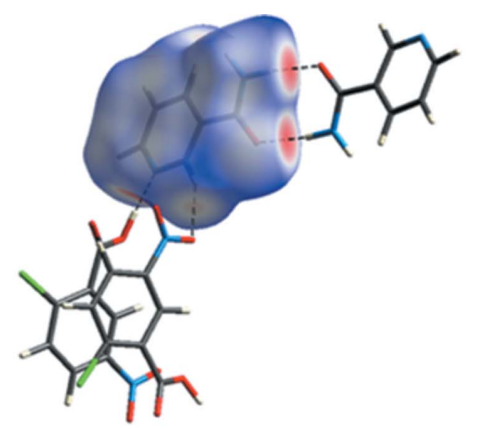

(ii) dnorm mapped over NIC co-crystal

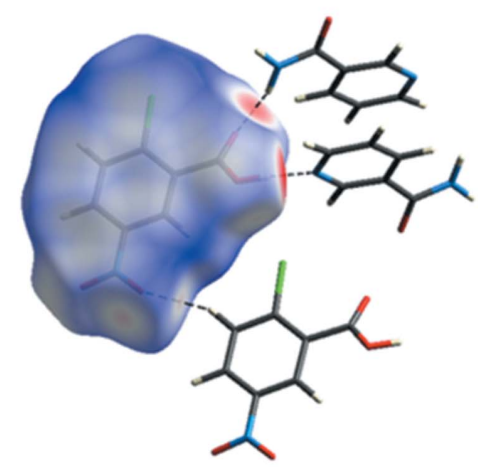

(iv)dnorm mapped over CNBA co-crystal

Hirshfeld surfaces developed on (i) $d_{\text {norm }}$ mapped over the pure NIC molecule, (ii) $d_{\text {norm }}$ mapped over the NIC molecule in title compound, (iii) $d_{\text {norm }}$ mapped over the pure CNBA molecule and (iv) $d_{\text {norm }}$ mapped over the CNBA molecule in title compound. 
Table 1

Hydrogen-bond geometry $\left(\AA,^{\circ}\right)$.

\begin{tabular}{lllll}
\hline$D-\mathrm{H} \cdots A$ & $D-\mathrm{H}$ & $\mathrm{H} \cdots A$ & $D \cdots A$ & $D-\mathrm{H} \cdots A$ \\
\hline $\mathrm{N} 1-\mathrm{H} 1 A \cdots \mathrm{O} 1$ & $0.90(2)$ & $2.005(19)$ & $2.9004(15)$ & $171.4(14)$ \\
$\mathrm{N} 1-\mathrm{H} 1 B \cdots \mathrm{O} 3$ & $0.873(19)$ & $2.116(19)$ & $2.9715(14)$ & $166.6(16)$ \\
$\mathrm{O} 2-\mathrm{H} 2 \cdots \mathrm{N} 2$ & $1.07(2)$ & $1.49(2)$ & $2.5543(13)$ & $172(2)$ \\
$\mathrm{C} 3-\mathrm{H} 3 \cdots \mathrm{O} 4$ & $0.986(15)$ & $2.516(15)$ & $3.4505(16)$ & $158.2(12)$ \\
$\mathrm{C} 4-\mathrm{H} 4 \cdots \mathrm{O} 5$ & $0.979(14)$ & $2.442(15)$ & $3.3256(17)$ & $149.9(12)$ \\
$\mathrm{C} 5-\mathrm{H} 5 \cdots \mathrm{O} 5$ & $0.956(15)$ & $2.450(16)$ & $3.0878(17)$ & $124.0(11)$ \\
$\mathrm{C} 6-\mathrm{H} 6 \cdots \mathrm{O} 3$ & $0.959(15)$ & $2.608(15)$ & $3.452(1)$ & $147.0(11)$ \\
$\mathrm{C} 10-\mathrm{H} 10 \cdots \mathrm{O} 4$ & $0.955(15)$ & $2.599(16)$ & $3.5010(18)$ & $157.6(15)$
\end{tabular}

hydrogen bonds are observed (Fig. 2 and Table 1). In this cocrystal, the NIC molecule forms a dimer with itself having an $R_{2}^{2}(8)$ graph-set motif (Etter et al., 1990). These dimers are
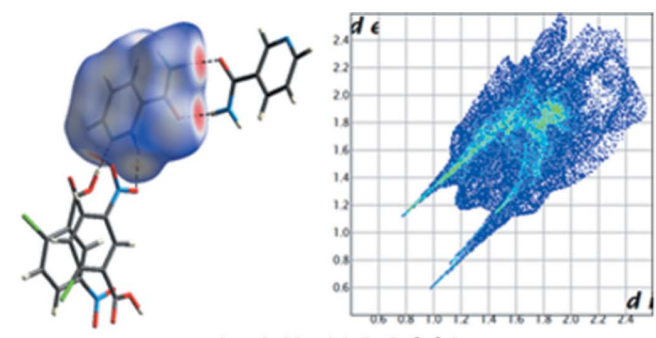

a) All (100\%)

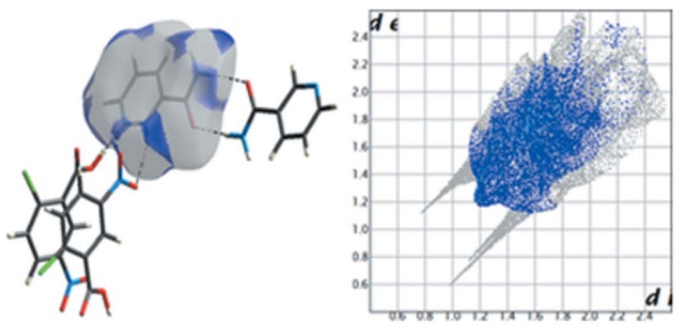

c) $\mathrm{H} \cdots \mathrm{H}(22 \%)$

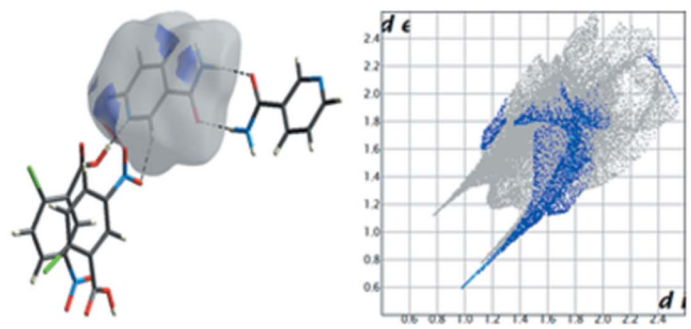

e) $\mathrm{N} \cdots \mathrm{H} / \mathrm{H} \cdots \mathrm{N}(8.9 \%)$

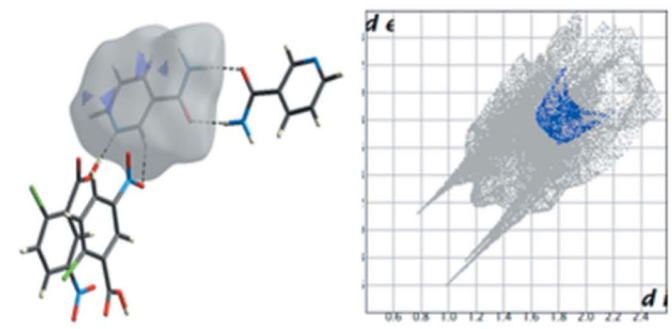

g) $\mathrm{C} \cdots \mathrm{N} / \mathrm{N} \cdots \mathrm{C}(3.1 \%)$ further connected via $\mathrm{C}-\mathrm{H} \cdots \mathrm{O}$ hydrogen bonding and form a tetrameric ring with two molecules each of NIC and CNBA with $R_{2}^{2}(10)$ graph-set motifs (Etter et al., 1990) (Fig. 2). Furthermore, weak $\pi-\pi$ interactions are observed for both NIC [3.68 (7) $\AA$ ] and CNBA [3.73 (7) $\AA$ ] which stabilize the molecular assembly along the $b c$ plane (Fig. 3).<smiles>O=C(O)c1cc([N+](=O)[O-])ccc1Cl</smiles><smiles>NC(=O)c1cccnc1</smiles>

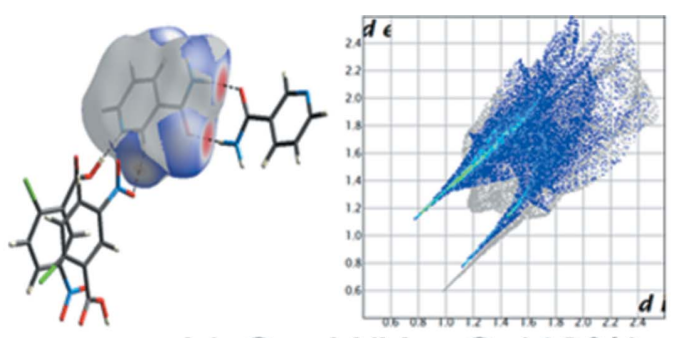

b) $\mathrm{O} \cdots \mathrm{H} / \mathrm{H} \cdots \mathrm{O}(40 \%)$

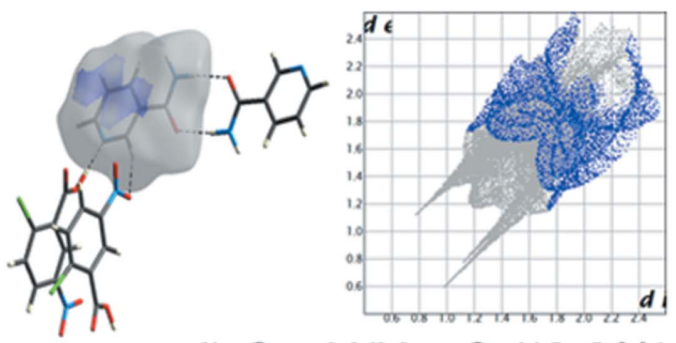

d) $\mathrm{C} \cdots \mathrm{H} / \mathrm{H} \cdots \mathrm{C}(13.8 \%)$

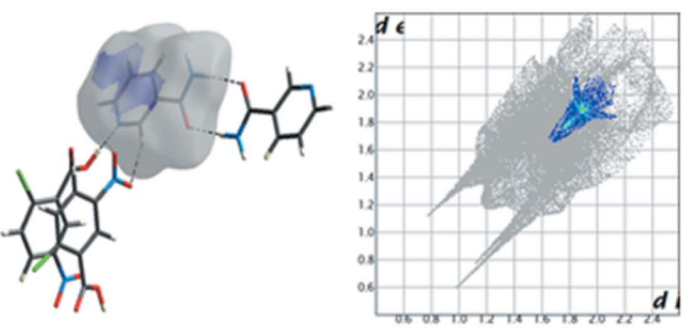

f) $\mathrm{C} \cdots \mathrm{C}(6.6 \%)$

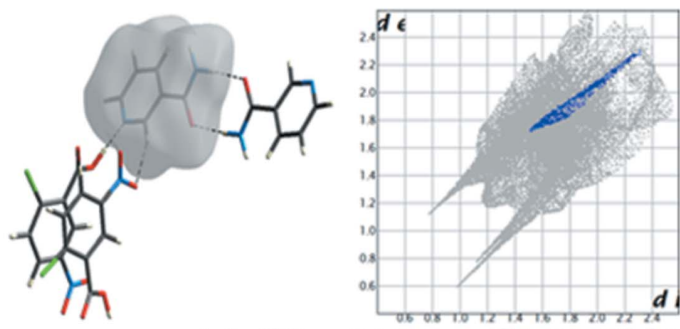

h) $\mathrm{Cl} \cdots \mathrm{N} / \mathrm{N} \cdots \mathrm{Cl}(1.6 \%)$

Figure 5

Two-dimensional fingerprint plots and relative contributions of various interactions to the Hirshfeld surface of the NIC cocrystal molecule. 


\section{Hirshfeld surface analysis}

To understand the role of intermolecular interactions, we have utilized the Hirshfeld surface analysis visualizing tool (Spackman \& Jayatilaka, 2009). The Hirshfeld surfaces and two-dimensional fingerprint plots developed using CrystalExplorer (Version 3.1; Wolff et al., 2012) are shown in Fig. 4. The red spot on the surface represents a strong interaction through $\mathrm{O}-\mathrm{H} \cdots \mathrm{N}$ and $\mathrm{N}-\mathrm{H} \cdots \mathrm{O}$ hydrogen bonding, whereas the blue color represents a lack of interaction. The $d_{\text {norm }}$ map of the title compound NIC.CNBA and its pure components is shown in Fig. 4, where individual molecular interactions were estimated. The fingerprint plot shows that $\mathrm{O} \cdots \mathrm{H} / \mathrm{H} \cdots \mathrm{O}$ and $\mathrm{H} \cdots \mathrm{H}$ contribute the major part of the interaction in all compounds (Fig. 4). The $\mathrm{O} \cdots \mathrm{H} / \mathrm{H} \cdots \mathrm{O}$ contact contributes $40 \%$ to the cocrystal NIC molecule (Fig. 5) and $20.5 \%$ to the pure NIC molecule (NICOAM01; Miwa et al., 1999) (Fig. 6), and $\mathrm{H} \cdot \mathrm{H}$ contributes $22 \%$ to the cocrystal NIC molecule and $41 \%$ to the pure NIC molecule. Similarly, $\mathrm{O} \cdots \mathrm{H} / \mathrm{H} \cdots \mathrm{O}$ contacts contribute $33 \%$ to the cocrystal CNBA molecule (Fig. 7) and $36.6 \%$ to the pure CNBA molecule (CLNBZA; Ferguson \& Sim, 1962) (Fig. 8), and $\mathrm{H} \cdots \mathrm{H}$ contributes $15.2 \%$ to the cocrystal CNBA molecule and $17.7 \%$ to the pure NIC molecule.

\section{Database survey}

A search for the title cocrystal in the Cambridge Structural Database (CSD, Version 5.40, update of February 2019;
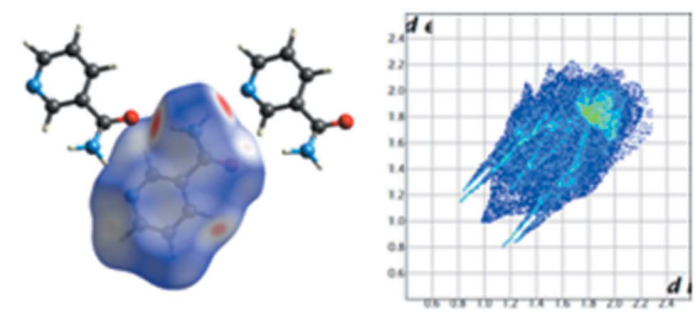

a) All (100\%)
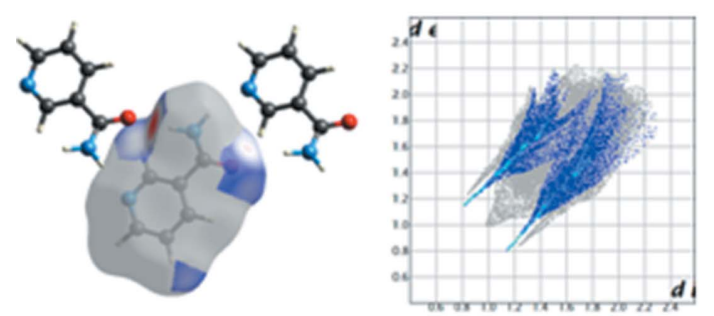

c) $\mathrm{O} \cdots \mathrm{H} / \mathrm{H} \cdots \mathrm{O}(20.5 \%)$
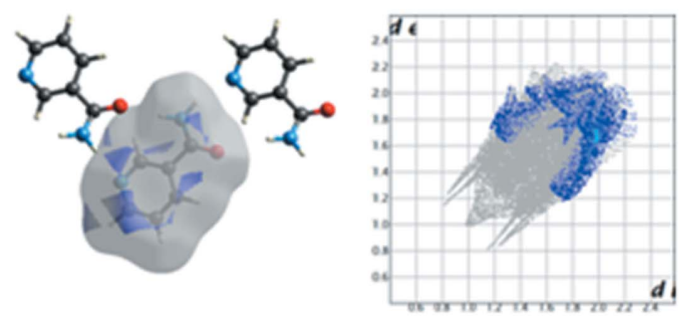

e) $\mathrm{C} \cdots \mathrm{H} / \mathrm{H} \cdots \mathrm{C}(10.1 \%)$
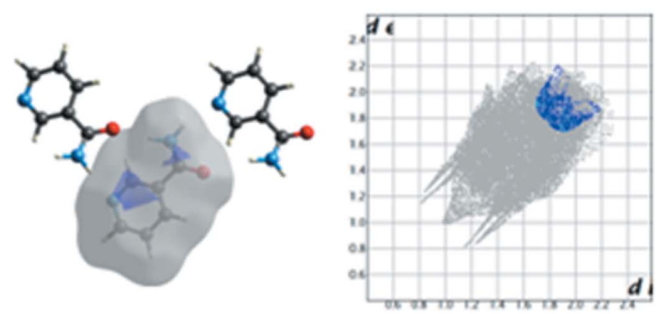

g) $C \cdots N / N \cdots C(4 \%)$
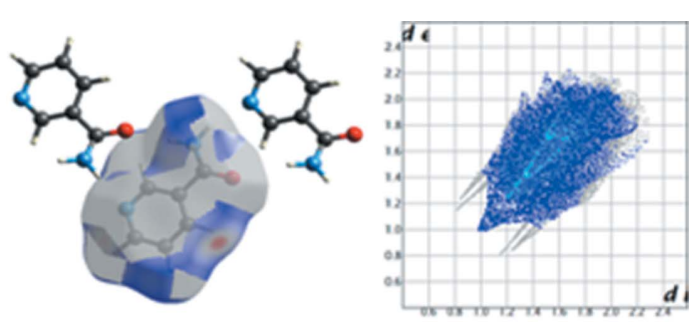

b) $\mathrm{H} \cdots \mathrm{H}(41 \%)$
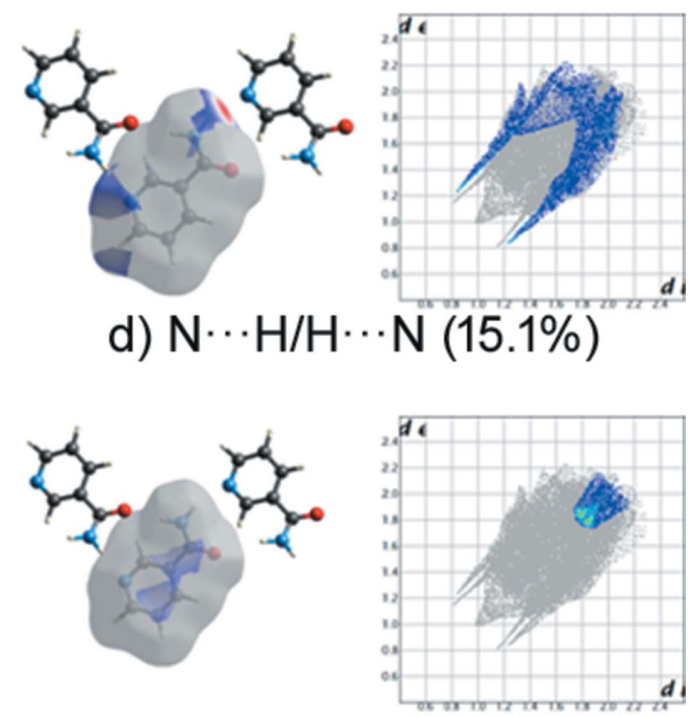

f) $C \cdots C(8.6 \%)$
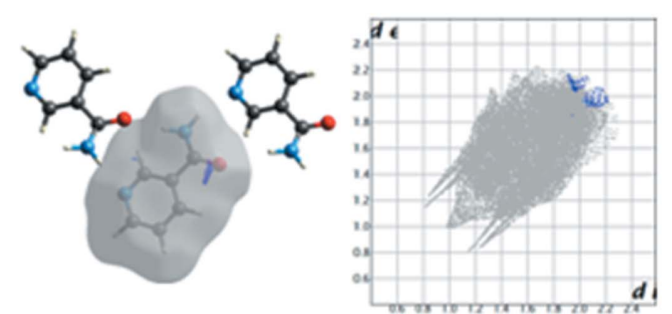

h) $\mathrm{C} \cdots \mathrm{O}(0.7 \%)$

Figure 6

Two-dimensional fingerprint plots and relative contributions of various interactions to the Hirshfeld surface of the pure NIC molecule. 
Groom et al., 2016) found no hits. However, searches for NIC and CNBA gave 237 and 9 hits, respectively. A search for the NIC molecule showed that the $\mathrm{N}$ atom on the phenyl ring forms strong $\mathrm{O}-\mathrm{H} \cdots \mathrm{N}$ hydrogen bonds with a carboxyl $\mathrm{H}$ atom in the most of the cocrystals [ABULIU (Lou \& $\mathrm{Hu}$, 2011), BICQAH (Aitipamula et al., 2013), BICQEL (Aitipamula et al., 2013), BOBQUG (Zhang et al., 2013), CUYXUQ (Lemmerer \& Bernstein, 2010), DINRUP (Lemmerer et al., 2013), DINSEA (Lemmerer et al., 2013), EDAPOQ (Orola \& Veidis, 2009) etc]. For the CNBA search, two structures were found similar to the title compound where strong hydrogen bonding is formed by the carboxyl $\mathrm{H}$ atom with a pyridine $\mathrm{N}$ atom [AJIWIA (Gotoh \& Ishida, 2009) and OCAZAT (Ishida et al., 2001)]. AJIWIA also shows halogen bonds through C-
$\mathrm{O} \cdots \mathrm{Cl}$ bonding and forms a dimer through $\mathrm{C}-\mathrm{H} \cdots \mathrm{O}$ hydrogen bonding.

\section{Synthesis and crystallization}

All the chemicals used for the synthesis were purchased from Alfa Aesar and used without further purification. A stock solution was prepared from an equimolar mixture of 2-chloro5 nitrobenzoic acid $(82.44 \mathrm{mg}, 0.409 \mathrm{mmol})$ and nicotinamide (50 mg, $0.409 \mathrm{mmol}$ ) in a minimum amount of ethanol and made up to a volume of $10 \mathrm{ml}$. Ten different combinations of the mixture were prepared using ethanol-hexane as the solvent mixture over the ratio range $1: 1$ to $1: 10$. The mixture was kept in a $5 \mathrm{ml}$ beaker and covered with parafilm, with four
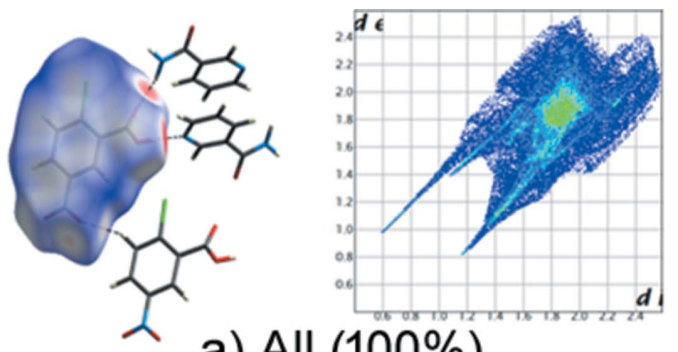

a) All (100\%)
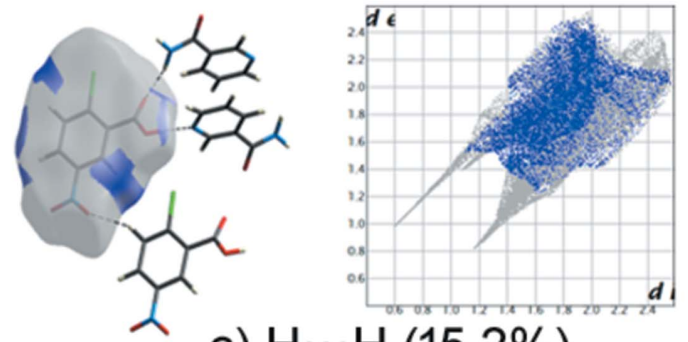

c) $\mathrm{H} \cdots \mathrm{H}(15.2 \%)$
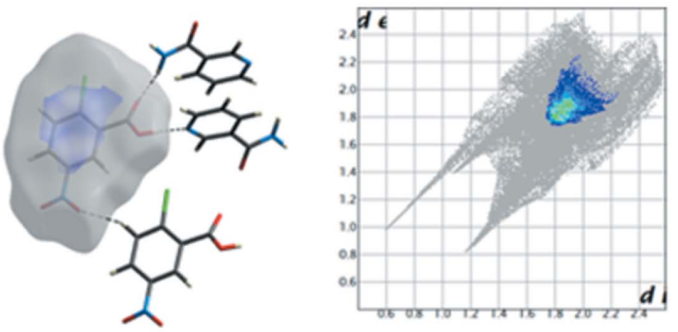

e) C $\cdots C(12.4 \%)$
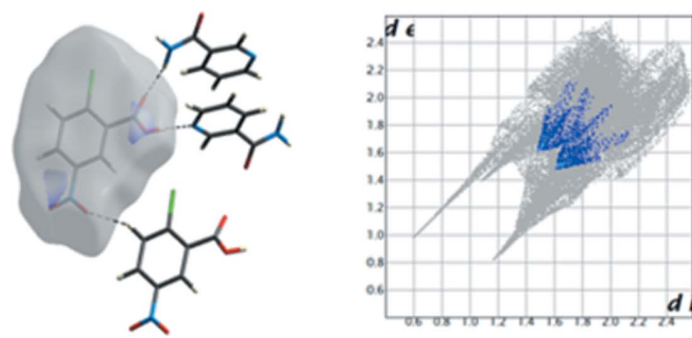

g) $\mathrm{O} \cdots \mathrm{N} / \mathrm{N} \cdots \mathrm{O}(3.8 \%)$
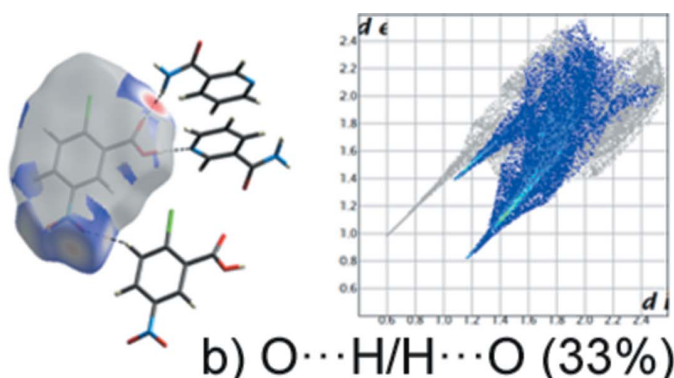

b) $\mathrm{O} \cdots \mathrm{H} / \mathrm{H} \cdots \mathrm{O}(33 \%)$
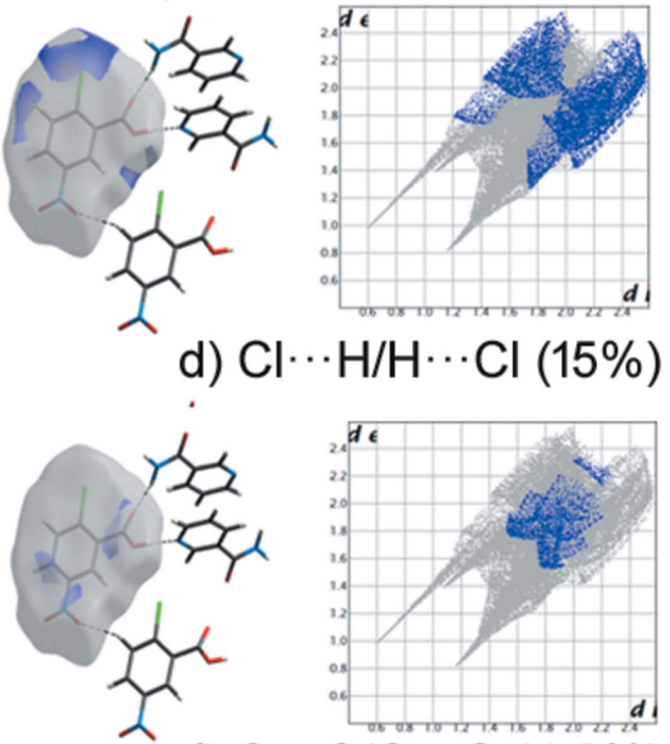

f) $\mathrm{O} \cdots \mathrm{C} / \mathrm{C} \cdots \mathrm{O}(4.8 \%)$

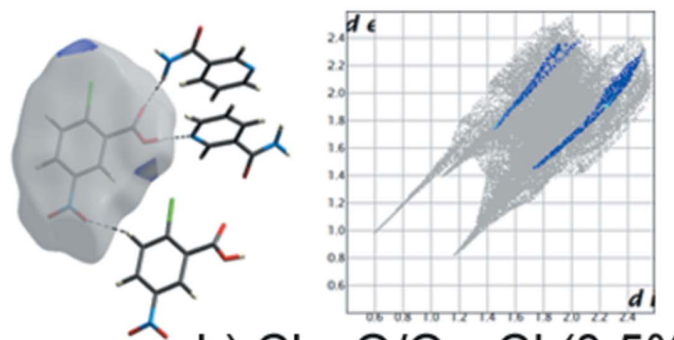

h) $\mathrm{Cl} \cdots \mathrm{O} / \mathrm{O} \cdots \mathrm{Cl}(3.5 \%)$

Figure 7

Two-dimensional fingerprint plots and relative contributions of various interactions to the Hirshfeld surface of the CNBA cocrystal molecule. 

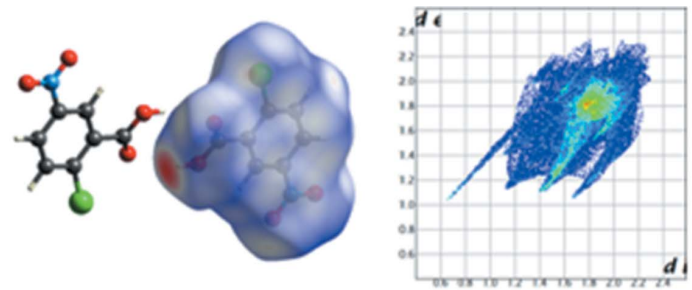

a) All (100\%)
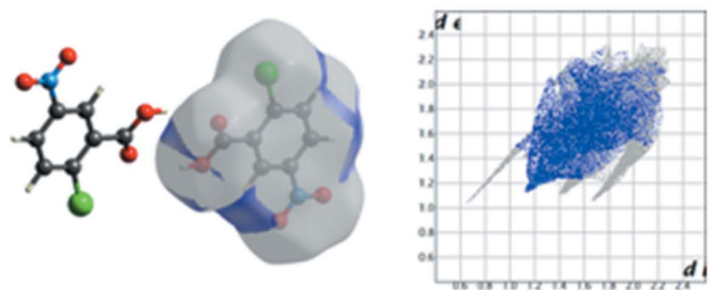

c) $\mathrm{H} \cdots \mathrm{H}(17.7 \%)$
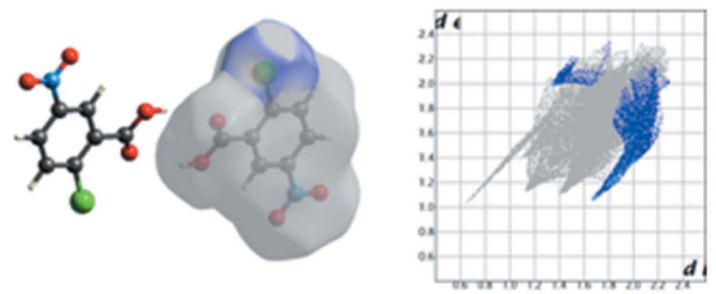

e) $\mathrm{H} \cdots \mathrm{Cl} / \mathrm{Cl} \cdots \mathrm{H}(10.1 \%)$
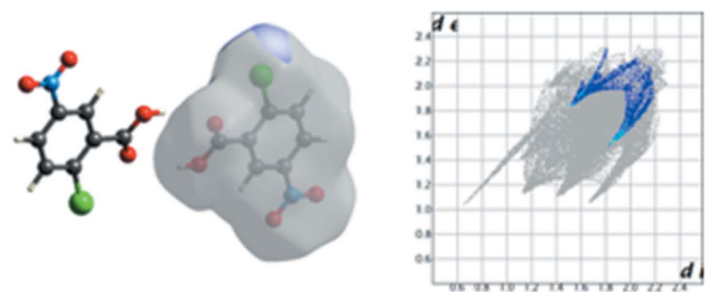

g) $\mathrm{O} \cdots \mathrm{Cl} / \mathrm{Cl} \cdots \mathrm{O}(5 \%)$
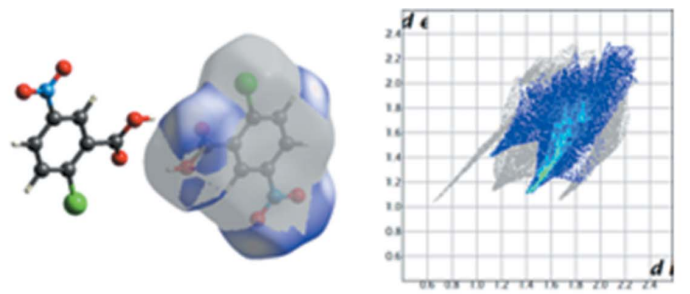

b) $\mathrm{O} \cdots \mathrm{H} / \mathrm{H} \cdots \mathrm{O}(36.6 \%)$
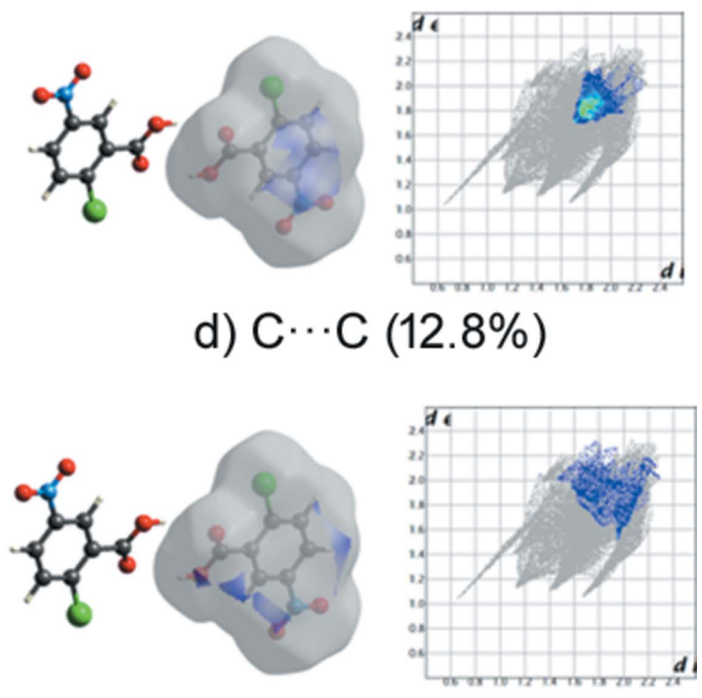

f) $\mathrm{O} \cdots \mathrm{Cl} / \mathrm{Cl} \cdots \mathrm{O}(5 \%)$
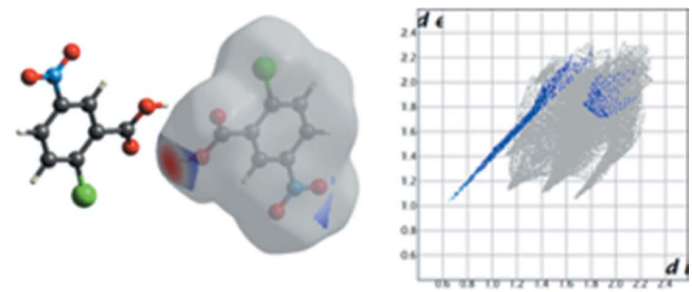

h) $\mathrm{C} \cdots \mathrm{H} / \mathrm{H} \cdots \mathrm{C}(4.3 \%)$

Figure 8

Two-dimensional fingerprint plots and relative contributions of various interactions to the Hirshfeld surface of the pure CNBA molecule

to five small holes in it. These solutions were allowed to evaporate slowly at room temperature $\left(27^{\circ} \mathrm{C}\right)$ over several days to obtain single crystals. After a few days, colourless crystals were obtained from ethanol-hexane solutions with concentration ratios of 1:10,1:2 and 1:4. The melting point of the obtained crystal was $159.7^{\circ} \mathrm{C}$.

\section{Refinement}

Crystal data, data collection, and structure refinement details are summarized in Table 2. All $\mathrm{H}$ atoms were found in a difference Fourier maps and were refind freely.

\section{Acknowledgements}

The authors are thankful to IISER, Bhopal, for the singlecrystal X-ray data collection.
Funding information

Funding for this research was provided by: National Research Foundation and Durban University of Technology, South Africa (grant Nos. 96807 and 98884), and SERB, DST India (grant No. ECR/2016/001820) for research support and instrument facilities.

\section{References}

Aitipamula, S., Wong, A. B., Chow, P. S. \& Tan, R. B. (2013). CrystEngComm, 15, 5877-5887.

Bruker (2001). SADABS. Bruker AXS Inc., Madison, Wisconsin, USA.

Bruker (2012). APEX2. Bruker AXS Inc., Madison, Wisconsin, USA.

Chenault, H. K. \& Whitesides, G. M. (1987). Appl. Biochem. Biotechnol. 14, 147-197.

Dolomanov, O. V., Bourhis, L. J., Gildea, R. J., Howard, J. A. K. \& Puschmann, H. (2009). J. Appl. Cryst. 42, 339-341. 
Table 2

Experimental details.

\begin{tabular}{|c|c|}
\hline \multicolumn{2}{|l|}{ Crystal data } \\
\hline Chemical formula & $\mathrm{C}_{7} \mathrm{H}_{4} \mathrm{ClNO}_{4} \cdot \mathrm{C}_{6} \mathrm{H}_{6} \mathrm{~N}_{2} \mathrm{O}$ \\
\hline$M_{\mathrm{r}}$ & 323.69 \\
\hline Crystal system, space group & Monoclinic, $P 2_{1} / c$ \\
\hline Temperature $(\mathrm{K})$ & 123 \\
\hline$a, b, c(\AA)$ & 7.4897 (1), $26.3607(5), 7.0623(1)$ \\
\hline$\beta\left(^{\circ}\right)$ & $96.356(1)$ \\
\hline$V\left(\AA^{3}\right)$ & $1385.77(4)$ \\
\hline$Z$ & 4 \\
\hline Radiation type & Мo $K \alpha$ \\
\hline$\mu\left(\mathrm{mm}^{-1}\right)$ & 0.31 \\
\hline Crystal size $(\mathrm{mm})$ & $0.28 \times 0.22 \times 0.15$ \\
\hline \multicolumn{2}{|l|}{ Data collection } \\
\hline Diffractometer & Bruker Kappa APEXII DUO \\
\hline Absorption correction & $\begin{array}{l}\text { Multi-scan (SADABS; Bruker, } \\
\text { 2001) }\end{array}$ \\
\hline$T_{\min }, T_{\max }$ & $0.874,0.908$ \\
\hline $\begin{array}{l}\text { No. of measured, independent and } \\
\text { observed }[I>2 \sigma(I)] \text { reflections }\end{array}$ & $29950,4123,3316$ \\
\hline$R_{\text {int }}$ & 0.037 \\
\hline$(\sin \theta / \lambda)_{\max }\left(\AA^{-1}\right)$ & 0.708 \\
\hline \multicolumn{2}{|l|}{ Refinement } \\
\hline$R\left[F^{2}>2 \sigma\left(F^{2}\right)\right], w R\left(F^{2}\right), S$ & $0.038,0.094,1.08$ \\
\hline No. of reflections & 4123 \\
\hline No. of parameters & 239 \\
\hline $\mathrm{H}$-atom treatment & All $\mathrm{H}$-atom parameters refined \\
\hline$\Delta \rho_{\max }, \Delta \rho_{\min }\left(\mathrm{e} \AA^{-3}\right)$ & $0.30,-0.26$ \\
\hline
\end{tabular}

Computer programs: APEX2 (Bruker, 2012), SAINT (Bruker, 2012), SHELXS18 (Sheldrick, 2015), SHELXL2018 (Sheldrick, 2015), Mercury (Macrae et al., 2008), OLEX2 (Dolomanov et al., 2009) and PLATON (Spek, 2009).

Dragovic, J., Kim, S. H., Brown, S. L. \& Kim, J. H. (1995). Radiother. Oncol. 36, 225-228.
Elliott, R., Pilcher, C., Stewart, A., Fergusson, D. \& McGregor, M. (1993). Ann. N. Y. Acad. Sci. 696, 333-341.

Etter, M. C., MacDonald, J. C. \& Bernstein, J. (1990). Acta Cryst. B46, 256-262.

Ferguson, G. \& Sim, G. (1962). J. Chem. Soc. pp. 1767-1775.

Gotoh, K. \& Ishida, H. (2009). Acta Cryst. C65, o534-o538.

Groom, C. R., Bruno, I. J., Lightfoot, M. P. \& Ward, S. C. (2016). Acta Cryst. B72, 171-179.

Horsman, M. R., Hoyer, M., Honess, D. J., Dennis, I. F. \& Overgaard, J. (1993). Radiother. Oncol. 27, 131-139.

Ishida, H., Rahman, B. \& Kashino, S. (2001). Acta Cryst. C57, 876879.

Lemmerer, A., Adsmond, D. A., Esterhuysen, C. \& Bernstein, J. (2013). Cryst. Growth Des. 13, 3935-3952.

Lemmerer, A. \& Bernstein, J. (2010). CrystEngComm, 12, 2029-2033.

Lemmerer, A., Esterhuysen, C. \& Bernstein, J. (2010). J. Pharm. Sci. 99, 4054-4071.

Lou, B. \& Hu, S. (2011). J. Chem. Crystallogr. 41, 1663-1668.

Macrae, C. F., Bruno, I. J., Chisholm, J. A., Edgington, P. R., McCabe, P., Pidcock, E., Rodriguez-Monge, L., Taylor, R., van de Streek, J. \& Wood, P. A. (2008). J. Appl. Cryst. 41, 466-470.

Miwa, Y., Mizuno, T., Tsuchida, K., Taga, T. \& Iwata, Y. (1999). Acta Cryst. B55, 78-84.

Orola, L. \& Veidis, M. V. (2009). CrystEngComm, 11, 415-417.

Schultheiss, N. \& Newman, A. (2009). Cryst. Growth Des. 9, 29502967.

Sheldrick, G. M. (2015). Acta Cryst. C71, 3-8.

Spackman, M. A. \& Jayatilaka, D. (2009). CrystEngComm, 11, 19-32. Spek, A. L. (2009). Acta Cryst. D65, 148-155.

Wolff, S., Grimwood, D., McKinnon, J., Turner, M., Jayatilaka, D. \& Spackman, M. (2012). CrystalExplorer. The University of Western Australia.

Zhang, S.-W., Harasimowicz, M. T., de Villiers, M. M. \& Yu, L. (2013). J. Am. Chem. Soc. 135, 18981-18989. 


\section{supporting information}

Acta Cryst. (2019). E75, 1712-1718 [https://doi.org/10.1107/S2056989019013859]

\section{Crystal structure of a 1:1 cocrystal of nicotinamide with 2-chloro-5-nitro- benzoic acid}

\section{Keshab M. Bairagi, Priyanka Pal, Subhrajyoti Bhandary, Katharigatta N. Venugopala, Deepak \\ Chopra and Susanta K. Nayak}

Computing details

Data collection: APEX2 (Bruker, 2012); cell refinement: SAINT (Bruker, 2012); data reduction: SAINT (Bruker, 2012); program(s) used to solve structure: SHELXS18 (Sheldrick, 2015); program(s) used to refine structure: SHELXL2018 (Sheldrick, 2015); molecular graphics: Mercury (Macrae et al., 2008); software used to prepare material for publication: OLEX2 (Dolomanov et al., 2009) and PLATON (Spek, 2009).

2-Chloro-5-nitrobenzoic acid-nicotinamide (1/1)

Crystal data

$\mathrm{C}_{7} \mathrm{H}_{4} \mathrm{ClNO}_{4} \cdot \mathrm{C}_{6} \mathrm{H}_{6} \mathrm{~N}_{2} \mathrm{O}$

$M_{r}=323.69$

Monoclinic, $P 2_{1} / c$

$a=7.4897$ (1) $\AA$

$b=26.3607(5) \AA$

$c=7.0623(1) \AA$

$\beta=96.356(1)^{\circ}$

$V=1385.77$ (4) $\AA^{3}$

$Z=4$

$F(000)=664$

Data collection

Bruker Kappa APEXII DUO diffractometer

Radiation source: fine-focus sealed tube Graphite monochromator $\omega$ scans

Absorption correction: multi-scan

(SADABS; Bruker, 2001)

$T_{\min }=0.874, T_{\max }=0.908$

Refinement

Refinement on $F^{2}$

Least-squares matrix: full

$R\left[F^{2}>2 \sigma\left(F^{2}\right)\right]=0.038$

$w R\left(F^{2}\right)=0.094$

$S=1.08$

4123 reflections

239 parameters

0 restraints
$D_{\mathrm{x}}=1.551 \mathrm{Mg} \mathrm{m}^{-3}$

Melting point: $159.7 \mathrm{~K}$

Mo $K \alpha$ radiation, $\lambda=0.71073 \AA$

Cell parameters from 4123 reflections

$\theta=1.5-30.2^{\circ}$

$\mu=0.31 \mathrm{~mm}^{-1}$

$T=123 \mathrm{~K}$

Block, colorless

$0.28 \times 0.22 \times 0.15 \mathrm{~mm}$

29950 measured reflections

4123 independent reflections

3316 reflections with $I>2 \sigma(I)$

$R_{\text {int }}=0.037$

$\theta_{\max }=30.2^{\circ}, \theta_{\min }=1.6^{\circ}$

$h=-10 \rightarrow 10$

$k=-37 \rightarrow 37$

$l=-9 \rightarrow 9$

Hydrogen site location: difference Fourier map

All $\mathrm{H}$-atom parameters refined

$w=1 /\left[\sigma^{2}\left(F_{\mathrm{o}}^{2}\right)+(0.0394 P)^{2}+0.4303 P\right]$

where $P=\left(F_{\mathrm{o}}^{2}+2 F_{\mathrm{c}}{ }^{2}\right) / 3$

$(\Delta / \sigma)_{\max }<0.001$

$\Delta \rho_{\max }=0.30 \mathrm{e} \AA^{-3}$

$\Delta \rho_{\min }=-0.26$ e $\AA^{-3}$ 


\section{Special details}

Geometry. All esds (except the esd in the dihedral angle between two 1.s. planes) are estimated using the full covariance matrix. The cell esds are taken into account individually in the estimation of esds in distances, angles and torsion angles; correlations between esds in cell parameters are only used when they are defined by crystal symmetry. An approximate (isotropic) treatment of cell esds is used for estimating esds involving l.s. planes.

Refinement. Single-crystal X-ray diffraction data were collected on a Bruker KAPPA APEX II DUO diffractometer using graphite-monochromated Mo-K $\alpha$ radiation $(\lambda=0.71073 \AA)$ (Bruker, 2012). The data collection was performed at 153 (2) $\mathrm{K}$. The temperature was monitored by an Oxford Cryostream cooling system (Oxford Cryostat). the program SAINT (Bruker, 2012) were used for cell refinement and data reduction. The data were scaled and absorption correction performed using SADABS(Bruker, 2001). The structure was solved by direct methods using SHELXS-18(Sheldrick, 2015) and refined by full-matrix least-squares methods based on F2 using SHELXL-2018/3(Sheldrick, 2015). The computing, Mercury(Macrae et al., 2008) and PLATON (Spek, 2009) were used for molecular graphics and molecular interactions. All non-hydrogen atoms were refined anisotropically.

Fractional atomic coordinates and isotropic or equivalent isotropic displacement parameters $\left(\AA^{2}\right)$

\begin{tabular}{|c|c|c|c|c|}
\hline & $x$ & $y$ & $z$ & $U_{\text {iso }} * / U_{\text {eq }}$ \\
\hline $\mathrm{Cl1}$ & $-0.18141(5)$ & $0.18331(2)$ & $0.33099(6)$ & $0.04137(12)$ \\
\hline $\mathrm{O} 2$ & $0.39368(12)$ & $0.16413(3)$ & $0.29015(14)$ & $0.0267(2)$ \\
\hline $\mathrm{O} 1$ & $0.87918(13)$ & $0.45197(3)$ & $1.35865(13)$ & $0.0268(2)$ \\
\hline $\mathrm{O} 5$ & $0.29333(16)$ & $0.39338(4)$ & $0.38136(16)$ & 0.0381 \\
\hline $\mathrm{O} 3$ & $0.16833(14)$ & $0.13103(3)$ & $0.43221(14)$ & $0.0308(2)$ \\
\hline $\mathrm{O} 4$ & $0.50015(15)$ & $0.34087(4)$ & $0.32242(18)$ & $0.0417(3)$ \\
\hline N1 & $0.87836(15)$ & $0.53606(4)$ & $1.29452(16)$ & $0.0226(2)$ \\
\hline $\mathrm{N} 2$ & $0.57395(14)$ & $0.41744(4)$ & $0.85619(15)$ & $0.0208(2)$ \\
\hline N3 & $0.34615(16)$ & $0.35059(4)$ & $0.35149(16)$ & $0.0262(2)$ \\
\hline C6 & $0.75383(15)$ & $0.50921(4)$ & $0.89924(17)$ & $0.0189(2)$ \\
\hline $\mathrm{C} 1$ & $0.83945(15)$ & $0.48801(4)$ & $1.24921(17)$ & $0.0193(2)$ \\
\hline $\mathrm{C} 2$ & $0.74506(15)$ & $0.47734(4)$ & $1.05512(16)$ & $0.0172(2)$ \\
\hline C12 & $0.21719(17)$ & $0.30889(4)$ & $0.35036(17)$ & $0.0209(2)$ \\
\hline $\mathrm{C} 4$ & $0.59051(17)$ & $0.44720(5)$ & $0.70484(18)$ & $0.0221(2)$ \\
\hline $\mathrm{C} 13$ & $0.28144(16)$ & $0.25993(4)$ & $0.35032(17)$ & $0.0193(2)$ \\
\hline $\mathrm{C} 5$ & $0.67736(17)$ & $0.49327(5)$ & $0.72106(18)$ & $0.0217(2)$ \\
\hline C9 & $-0.02066(17)$ & $0.23039(5)$ & $0.34499(19)$ & $0.0243(3)$ \\
\hline $\mathrm{C} 3$ & $0.65244(16)$ & $0.43172(4)$ & $1.02733(17)$ & $0.0201(2)$ \\
\hline $\mathrm{C} 8$ & $0.16239(16)$ & $0.21927(4)$ & $0.35036(16)$ & $0.0191(2)$ \\
\hline $\mathrm{C} 10$ & $-0.08225(18)$ & $0.28024(5)$ & $0.3432(2)$ & $0.0291(3)$ \\
\hline $\mathrm{C} 7$ & $0.24078(17)$ & $0.16659(4)$ & $0.36051(17)$ & $0.0205(2)$ \\
\hline $\mathrm{C} 11$ & $0.03681(19)$ & $0.32024(5)$ & $0.34746(19)$ & 0.0261 \\
\hline $\mathrm{H} 3$ & $0.639(2)$ & $0.4084(6)$ & $1.134(2)$ & $0.022(4)^{*}$ \\
\hline H6 & $0.813(2)$ & $0.5415(6)$ & $0.909(2)$ & $0.022(4)^{*}$ \\
\hline H13 & $0.404(2)$ & $0.2537(6)$ & $0.352(2)$ & $0.028(4)^{*}$ \\
\hline H4 & $0.540(2)$ & $0.4339(6)$ & $0.581(2)$ & $0.025(4)^{*}$ \\
\hline H5 & $0.691(2)$ & $0.5138(6)$ & $0.612(2)$ & $0.026(4)^{*}$ \\
\hline $\mathrm{H} 1 \mathrm{~A}$ & $0.947(2)$ & $0.5426(6)$ & $1.405(3)$ & $0.035(4)^{*}$ \\
\hline H1B & $0.850(2)$ & $0.5613(7)$ & $1.216(3)$ & $0.038(5)^{*}$ \\
\hline H11 & $-0.006(2)$ & $0.3550(7)$ & $0.346(3)$ & $0.040(5)^{*}$ \\
\hline $\mathrm{H} 10$ & $-0.208(3)$ & $0.2870(7)$ & $0.338(3)$ & $0.042(5)^{*}$ \\
\hline $\mathrm{H} 2$ & $0.462(3)$ & $0.1292(9)$ & $0.326(3)$ & $0.074(7)^{*}$ \\
\hline
\end{tabular}


Atomic displacement parameters $\left(\AA^{2}\right)$

\begin{tabular}{|c|c|c|c|c|c|c|}
\hline & $U^{11}$ & $U^{22}$ & $U^{33}$ & $U^{12}$ & $U^{13}$ & $U^{23}$ \\
\hline $\mathrm{Cl} 1$ & $0.02685(18)$ & $0.0403(2)$ & $0.0562(3)$ & $-0.01523(14)$ & $0.00135(15)$ & $0.00272(16)$ \\
\hline $\mathrm{O} 2$ & $0.0251(5)$ & $0.0190(4)$ & $0.0362(5)$ & $0.0037(3)$ & $0.0040(4)$ & $0.0050(4)$ \\
\hline $\mathrm{O} 1$ & $0.0362(5)$ & $0.0207(4)$ & $0.0216(5)$ & $-0.0011(4)$ & $-0.0050(4)$ & $0.0024(3)$ \\
\hline O5 & $0.0529(7)$ & $0.0147(4)$ & $0.0430(6)$ & $-0.0008(4)$ & $-0.0109(5)$ & $-0.0029(4)$ \\
\hline $\mathrm{O} 3$ & $0.0424(6)$ & $0.0172(4)$ & $0.0346(5)$ & $-0.0037(4)$ & 0.0115 (4) & 0.0017 (4) \\
\hline $\mathrm{O} 4$ & $0.0345(6)$ & $0.0268(5)$ & $0.0654(8)$ & $-0.0094(4)$ & $0.0126(5)$ & $0.0039(5)$ \\
\hline N1 & $0.0265(5)$ & $0.0186(5)$ & $0.0213(5)$ & $0.0006(4)$ & $-0.0040(4)$ & $-0.0017(4)$ \\
\hline $\mathrm{N} 2$ & $0.0211(5)$ & $0.0163(5)$ & $0.0243(5)$ & $-0.0016(4)$ & $-0.0008(4)$ & $-0.0014(4)$ \\
\hline N3 & $0.0357(6)$ & $0.0165(5)$ & $0.0253(6)$ & $-0.0031(4)$ & $-0.0022(4)$ & $0.0021(4)$ \\
\hline C6 & $0.0196(5)$ & $0.0151(5)$ & $0.0220(6)$ & $-0.0004(4)$ & $0.0022(4)$ & -0.0009 (4) \\
\hline $\mathrm{C} 1$ & $0.0187(5)$ & $0.0192(6)$ & $0.0200(6)$ & $0.0007(4)$ & $0.0023(4)$ & -0.0015 (4) \\
\hline $\mathrm{C} 2$ & $0.0167(5)$ & $0.0164(5)$ & $0.0184(5)$ & 0.0018 & 0.0015 (4) & $-0.0014(4)$ \\
\hline $\mathrm{C} 12$ & $0.0275(6)$ & $0.0164(5)$ & $0.0184(6)$ & $-0.0018(4)$ & 0.0006 (4) & $0.0000(4)$ \\
\hline $\mathrm{C} 4$ & $0.0247(6)$ & $0.0197(6)$ & $0.0207(6)$ & $0.0010(5)$ & $-0.0022(5)$ & $-0.0025(4)$ \\
\hline $\mathrm{C} 13$ & $0.0209(5)$ & $0.0183(5)$ & $0.0186(6)$ & $-0.0003(4)$ & $0.0011(4)$ & $0.0004(4)$ \\
\hline $\mathrm{C} 5$ & $0.0268(6)$ & $0.0184(6)$ & $0.0194(6)$ & 0.0004 (4) & $0.0006(5)$ & 0.0017 (4) \\
\hline C9 & $0.0216(6)$ & $0.0256(6)$ & $0.0257(6)$ & $-0.0044(5)$ & $0.0025(5)$ & $0.0000(5)$ \\
\hline $\mathrm{C} 3$ & $0.0216(5)$ & $0.0173(5)$ & $0.0212(6)$ & $-0.0002(4)$ & 0.0015 (4) & $0.0001(4)$ \\
\hline $\mathrm{C} 8$ & $0.0216(5)$ & $0.0177(5)$ & $0.0177(6)$ & $-0.0017(4)$ & 0.0012 (4) & $-0.0002(4)$ \\
\hline $\mathrm{C} 10$ & $0.0217(6)$ & $0.0320(7)$ & $0.0335(7)$ & $0.0045(5)$ & $0.0027(5)$ & $0.0004(5)$ \\
\hline $\mathrm{C} 7$ & $0.0266(6)$ & $0.0167(5)$ & $0.0174(6)$ & $-0.0019(4)$ & $-0.0011(4)$ & $-0.0008(4)$ \\
\hline $\mathrm{C} 11$ & $0.0305(7)$ & $0.0218(6)$ & $0.0255(7)$ & $0.0061(5)$ & $0.0010(5)$ & $-0.0004(5)$ \\
\hline
\end{tabular}

Geometric parameters $\left(\AA,{ }^{\circ}\right)$

\begin{tabular}{llll}
\hline $\mathrm{C} 11-\mathrm{C} 9$ & $1.7244(13)$ & $\mathrm{C} 1-\mathrm{C} 2$ & $1.4977(16)$ \\
$\mathrm{O} 2-\mathrm{C} 7$ & $1.2994(15)$ & $\mathrm{C} 2-\mathrm{C} 3$ & $1.3913(16)$ \\
$\mathrm{O} 2-\mathrm{H} 2$ & $1.07(2)$ & $\mathrm{C} 12-\mathrm{C} 13$ & $1.3774(16)$ \\
$\mathrm{O} 1-\mathrm{C} 1$ & $1.2399(14)$ & $\mathrm{C} 12-\mathrm{C} 11$ & $1.3816(18)$ \\
$\mathrm{O} 5-\mathrm{N} 3$ & $1.2215(15)$ & $\mathrm{C} 4-\mathrm{C} 5$ & $1.3766(17)$ \\
$\mathrm{O} 3-\mathrm{C} 7$ & $1.2208(14)$ & $\mathrm{C} 4-\mathrm{H} 4$ & $0.977(16)$ \\
$\mathrm{O} 4-\mathrm{N} 3$ & $1.2209(16)$ & $\mathrm{C} 13-\mathrm{C} 8$ & $1.3941(16)$ \\
$\mathrm{N} 1-\mathrm{C} 1$ & $1.3307(16)$ & $\mathrm{C} 13-\mathrm{H} 13$ & $0.932(16)$ \\
$\mathrm{N} 1-\mathrm{H} 1 \mathrm{~A}$ & $0.901(19)$ & $\mathrm{C} 5-\mathrm{H} 5$ & $0.957(16)$ \\
$\mathrm{N} 1-\mathrm{H} 1 \mathrm{~B}$ & $0.876(18)$ & $\mathrm{C} 9-\mathrm{C} 10$ & $1.3921(19)$ \\
$\mathrm{N} 2-\mathrm{C} 3$ & $1.3383(16)$ & $\mathrm{C} 9-\mathrm{C} 8$ & $1.3984(17)$ \\
$\mathrm{N} 2-\mathrm{C} 4$ & $1.3426(16)$ & $\mathrm{C} 3-\mathrm{H} 3$ & $0.984(15)$ \\
$\mathrm{N} 3-\mathrm{C} 12$ & $1.4626(16)$ & $\mathrm{C} 8-\mathrm{C} 7$ & $1.5064(16)$ \\
$\mathrm{C} 6-\mathrm{C} 5$ & $1.3887(17)$ & $\mathrm{C} 10-\mathrm{C} 11$ & $0.955(18)$ \\
$\mathrm{C} 6-\mathrm{C} 2$ & $1.3922(16)$ & $\mathrm{C} 10-\mathrm{H} 10$ & $0.971(18)$ \\
$\mathrm{C} 6-\mathrm{H} 6$ & $0.959(15)$ & $\mathrm{C} 11-\mathrm{H} 11$ & $120.6(9)$ \\
& & & $119.6(9)$ \\
$\mathrm{C} 7-\mathrm{O} 2-\mathrm{H} 2$ & $111.9(13)$ & $\mathrm{C} 12-\mathrm{C} 13-\mathrm{H} 13$ & $119.08(11)$ \\
$\mathrm{C} 1-\mathrm{N} 1-\mathrm{H} 1 \mathrm{~A}$ & $118.6(11)$ & $\mathrm{C} 8-\mathrm{C} 13-\mathrm{H} 13$ & \\
$\mathrm{C} 1-\mathrm{N} 1-\mathrm{H} 1 \mathrm{~B}$ & $122.7(12)$ & $\mathrm{C} 4-\mathrm{C} 5-\mathrm{C} 6$ &
\end{tabular}




\begin{tabular}{|c|c|c|c|}
\hline $\mathrm{H} 1 \mathrm{~A}-\mathrm{N} 1-\mathrm{H} 1 \mathrm{~B}$ & $118.4(16)$ & $\mathrm{C} 4-\mathrm{C} 5-\mathrm{H} 5$ & $121.5(9)$ \\
\hline $\mathrm{C} 3-\mathrm{N} 2-\mathrm{C} 4$ & $118.98(10)$ & $\mathrm{C} 6-\mathrm{C} 5-\mathrm{H} 5$ & $119.4(9)$ \\
\hline $\mathrm{O} 4-\mathrm{N} 3-\mathrm{O} 5$ & $123.56(12)$ & $\mathrm{C} 10-\mathrm{C} 9-\mathrm{C} 8$ & $121.40(11)$ \\
\hline $\mathrm{O} 4-\mathrm{N} 3-\mathrm{C} 12$ & $118.49(11)$ & $\mathrm{C} 10-\mathrm{C} 9-\mathrm{Cl}$ & $116.76(10)$ \\
\hline $\mathrm{O} 5-\mathrm{N} 3-\mathrm{C} 12$ & $117.95(12)$ & $\mathrm{C} 8-\mathrm{C} 9-\mathrm{Cl} 1$ & $121.80(10)$ \\
\hline $\mathrm{C} 5-\mathrm{C} 6-\mathrm{C} 2$ & $118.89(11)$ & $\mathrm{N} 2-\mathrm{C} 3-\mathrm{C} 2$ & $122.20(11)$ \\
\hline $\mathrm{C} 5-\mathrm{C} 6-\mathrm{H} 6$ & $118.5(9)$ & $\mathrm{N} 2-\mathrm{C} 3-\mathrm{H} 3$ & $116.1(9)$ \\
\hline $\mathrm{C} 2-\mathrm{C} 6-\mathrm{H} 6$ & $122.6(9)$ & $\mathrm{C} 2-\mathrm{C} 3-\mathrm{H} 3$ & $121.7(9)$ \\
\hline $\mathrm{O} 1-\mathrm{C} 1-\mathrm{N} 1$ & $123.25(11)$ & $\mathrm{C} 13-\mathrm{C} 8-\mathrm{C} 9$ & $117.65(11)$ \\
\hline $\mathrm{O} 1-\mathrm{C} 1-\mathrm{C} 2$ & $118.88(10)$ & $\mathrm{C} 13-\mathrm{C} 8-\mathrm{C} 7$ & $117.57(10)$ \\
\hline $\mathrm{N} 1-\mathrm{C} 1-\mathrm{C} 2$ & $117.87(11)$ & $\mathrm{C} 9-\mathrm{C} 8-\mathrm{C} 7$ & $124.77(11)$ \\
\hline $\mathrm{C} 3-\mathrm{C} 2-\mathrm{C} 6$ & $118.46(11)$ & $\mathrm{C} 11-\mathrm{C} 10-\mathrm{C} 9$ & $120.57(12)$ \\
\hline $\mathrm{C} 3-\mathrm{C} 2-\mathrm{C} 1$ & $117.96(10)$ & $\mathrm{C} 11-\mathrm{C} 10-\mathrm{H} 10$ & $119.3(11)$ \\
\hline $\mathrm{C} 6-\mathrm{C} 2-\mathrm{C} 1$ & $123.47(10)$ & C9-C10-H10 & $120.1(11)$ \\
\hline $\mathrm{C} 13-\mathrm{C} 12-\mathrm{C} 11$ & $122.95(11)$ & $\mathrm{O} 3-\mathrm{C} 7-\mathrm{O} 2$ & $124.84(11)$ \\
\hline $\mathrm{C} 13-\mathrm{C} 12-\mathrm{N} 3$ & $118.27(11)$ & $\mathrm{O} 3-\mathrm{C} 7-\mathrm{C} 8$ & $122.60(11)$ \\
\hline $\mathrm{C} 11-\mathrm{C} 12-\mathrm{N} 3$ & $118.78(11)$ & $\mathrm{O} 2-\mathrm{C} 7-\mathrm{C} 8$ & $112.54(10)$ \\
\hline $\mathrm{N} 2-\mathrm{C} 4-\mathrm{C} 5$ & $122.26(11)$ & $\mathrm{C} 10-\mathrm{C} 11-\mathrm{C} 12$ & $117.62(12)$ \\
\hline $\mathrm{N} 2-\mathrm{C} 4-\mathrm{H} 4$ & $116.2(9)$ & $\mathrm{C} 10-\mathrm{C} 11-\mathrm{H} 11$ & $120.6(11)$ \\
\hline $\mathrm{C} 5-\mathrm{C} 4-\mathrm{H} 4$ & $121.6(9)$ & $\mathrm{C} 12-\mathrm{C} 11-\mathrm{H} 11$ & $121.8(11)$ \\
\hline $\mathrm{C} 12-\mathrm{C} 13-\mathrm{C} 8$ & $119.79(11)$ & & \\
\hline $\mathrm{C} 5-\mathrm{C} 6-\mathrm{C} 2-\mathrm{C} 3$ & $-2.96(17)$ & $\mathrm{C} 1-\mathrm{C} 2-\mathrm{C} 3-\mathrm{N} 2$ & $-175.60(10)$ \\
\hline $\mathrm{C} 5-\mathrm{C} 6-\mathrm{C} 2-\mathrm{C} 1$ & $173.20(11)$ & $\mathrm{C} 12-\mathrm{C} 13-\mathrm{C} 8-\mathrm{C} 9$ & $1.77(17)$ \\
\hline $\mathrm{O} 1-\mathrm{C} 1-\mathrm{C} 2-\mathrm{C} 3$ & $21.57(16)$ & $\mathrm{C} 12-\mathrm{C} 13-\mathrm{C} 8-\mathrm{C} 7$ & $-176.93(11)$ \\
\hline $\mathrm{N} 1-\mathrm{C} 1-\mathrm{C} 2-\mathrm{C} 3$ & $-159.19(11)$ & $\mathrm{C} 10-\mathrm{C} 9-\mathrm{C} 8-\mathrm{C} 13$ & $-1.15(19)$ \\
\hline $\mathrm{O} 1-\mathrm{C} 1-\mathrm{C} 2-\mathrm{C} 6$ & $-154.61(12)$ & $\mathrm{C} 11-\mathrm{C} 9-\mathrm{C} 8-\mathrm{C} 13$ & $176.29(9)$ \\
\hline $\mathrm{N} 1-\mathrm{C} 1-\mathrm{C} 2-\mathrm{C} 6$ & $24.63(17)$ & $\mathrm{C} 10-\mathrm{C} 9-\mathrm{C} 8-\mathrm{C} 7$ & $177.44(12)$ \\
\hline $\mathrm{O} 4-\mathrm{N} 3-\mathrm{C} 12-\mathrm{C} 13$ & $11.29(17)$ & $\mathrm{C} 11-\mathrm{C} 9-\mathrm{C} 8-\mathrm{C} 7$ & $-5.12(18)$ \\
\hline $\mathrm{O} 5-\mathrm{N} 3-\mathrm{C} 12-\mathrm{C} 13$ & $-168.81(12)$ & $\mathrm{C} 8-\mathrm{C} 9-\mathrm{C} 10-\mathrm{C} 11$ & $-0.3(2)$ \\
\hline $\mathrm{O} 4-\mathrm{N} 3-\mathrm{C} 12-\mathrm{C} 11$ & $-168.07(12)$ & $\mathrm{C} 11-\mathrm{C} 9-\mathrm{C} 10-\mathrm{C} 11$ & $-177.83(11)$ \\
\hline $\mathrm{O} 5-\mathrm{N} 3-\mathrm{C} 12-\mathrm{C} 11$ & $11.83(17)$ & $\mathrm{C} 13-\mathrm{C} 8-\mathrm{C} 7-\mathrm{O} 3$ & $151.23(12)$ \\
\hline $\mathrm{C} 3-\mathrm{N} 2-\mathrm{C} 4-\mathrm{C} 5$ & $-3.55(18)$ & $\mathrm{C} 9-\mathrm{C} 8-\mathrm{C} 7-\mathrm{O} 3$ & $-27.36(19)$ \\
\hline $\mathrm{C} 11-\mathrm{C} 12-\mathrm{C} 13-\mathrm{C} 8$ & $-1.03(19)$ & $\mathrm{C} 13-\mathrm{C} 8-\mathrm{C} 7-\mathrm{O} 2$ & $-26.97(15)$ \\
\hline $\mathrm{N} 3-\mathrm{C} 12-\mathrm{C} 13-\mathrm{C} 8$ & $179.64(11)$ & $\mathrm{C} 9-\mathrm{C} 8-\mathrm{C} 7-\mathrm{O} 2$ & $154.44(12)$ \\
\hline $\mathrm{N} 2-\mathrm{C} 4-\mathrm{C} 5-\mathrm{C} 6$ & $1.33(19)$ & $\mathrm{C} 9-\mathrm{C} 10-\mathrm{C} 11-\mathrm{C} 12$ & $1.0(2)$ \\
\hline $\mathrm{C} 2-\mathrm{C} 6-\mathrm{C} 5-\mathrm{C} 4$ & $1.97(17)$ & $\mathrm{C} 13-\mathrm{C} 12-\mathrm{C} 11-\mathrm{C} 10$ & $-0.4(2)$ \\
\hline $\mathrm{C} 4-\mathrm{N} 2-\mathrm{C} 3-\mathrm{C} 2$ & $2.47(17)$ & $\mathrm{N} 3-\mathrm{C} 12-\mathrm{C} 11-\mathrm{C} 10$ & $178.92(12)$ \\
\hline $\mathrm{C} 6-\mathrm{C} 2-\mathrm{C} 3-\mathrm{N} 2$ & $0.78(17)$ & & \\
\hline
\end{tabular}

Hydrogen-bond geometry $\left(A,{ }^{\circ}\right)$

\begin{tabular}{lllll}
\hline$D-\mathrm{H} \cdots A$ & $D-\mathrm{H}$ & $\mathrm{H} \cdots A$ & $D \cdots A$ & $D-\mathrm{H} \cdots A$ \\
\hline $\mathrm{N} 1-\mathrm{H} 1 A \cdots \mathrm{O} 1$ & $0.90(2)$ & $2.005(19)$ & $2.9004(15)$ & $171.4(14)$ \\
$\mathrm{N} 1-\mathrm{H} 1 B \cdots \mathrm{O} 3$ & $0.873(19)$ & $2.116(19)$ & $2.9715(14)$ & $166.6(16)$ \\
$\mathrm{O} 2-\mathrm{H} 2 \cdots \mathrm{N} 2$ & $1.07(2)$ & $1.49(2)$ & $2.5543(13)$ & $172(2)$ \\
$\mathrm{C} 3-\mathrm{H} 3 \cdots \mathrm{O} 4$ & $0.986(15)$ & $2.516(15)$ & $3.4505(16)$ & $158.2(12)$ \\
$\mathrm{C} 4-\mathrm{H} 4 \cdots \mathrm{O} 5$ & $0.979(14)$ & $2.442(15)$ & $3.3256(17)$ & $149.9(12)$
\end{tabular}


supporting information

$\mathrm{C} 5-\mathrm{H} 5 \cdots \mathrm{O} 5$

$\mathrm{C} 6-\mathrm{H} 6 \cdots \mathrm{O} 3$

$\mathrm{C} 10-\mathrm{H} 10 \cdots \mathrm{O} 4$
$0.956(15)$

$0.959(15)$

$0.955(15)$
$2.450(16)$

$2.608(15)$

$2.599(16)$
$3.0878(17) \quad 124.0(11)$

$3.452(1)$

$147.0(11)$

$3.5010(18)$

$157.6(15)$ 